\title{
Anuran fauna of the Parque Estadual Carlos Botelho - Núcleo Sete Barras, southeastern Brazil: species composition, use of breeding sites, and seasonal patterns of breeding activity
}

\author{
Jaime Bertoluci ${ }^{1 *(D)}$, Henrique Oliveira Sawakuchi ${ }^{2}$, Carolina Ortiz ${ }^{1}$, Ricardo Augusto Brassaloti ${ }^{1}$, \\ José Wagner Ribeiro-Júnior ${ }^{3} \&$ Shirley Famelli ${ }^{1}$ \\ ${ }^{1}$ Universidade de São Paulo, Escola Superior de Agricultura Luiz de Queiroz, Departamento de Ciências \\ Biológicas, Av. Pádua Dias 11, 13418-900, Piracicaba, SP, Brasil. \\ ${ }^{2}$ Linköping University, Department of Thematic Studies, Environmental Change, Linköping, SE-581 83, Sweden. \\ ${ }^{3}$ Universidade Estadual Paulista, Instituto de Biociências, Av. 24A 1515, Rio Claro, SP, Brasil. \\ *Corresponding author: Jaime Bertoluci, e-mail: jaime.bertoluci@usp.br
}

BERTOLUCI, J., SAWAKUCHI H.O., ORTIZ, C., BRASSALOTI, R.A., RIBEIRO-JÚNIOR, J.W., FAMELLI, S. Anuran fauna of the Parque Estadual Carlos Botelho - Núcleo Sete Barras, southeastern Brazil: species composition, use of breeding sites, and seasonalpatterns of breeding activity. Biota Neotropica 21(1): e20201082. https://doi.org/10.1590/1676-0611-BN-2020-1082

\begin{abstract}
The goal of this work was to study the species composition, the use of breeding sites, and the seasonal patterns of breeding activity of the anuran fauna from Parque Estadual Carlos Botelho - Núcleo Sete Barras, state of São Paulo, southeastern Brazil. Fieldwork was carried out from September 2005 to October 2007 through two main methods: active visual search inside a 10 ha- permanent plot and aural and visual search in seven previously selected aquatic breeding habitats. Species richness was related to the sampling effort by means of species accumulation curve and through non-parametric estimators. Thirty-three species distributed in 12 families were recorded, from which 69\% are endemic to the Atlantic Forest. Trachycephalus mesophaeus represents a new record for the park. Cycloramphus lutzorum is included as Data Deficient in the IUCN list. The species accumulation curve did not stabilize, showing some tendency to rise. The use of breeding sites by 20 species was compared using cluster analysis, which revealed two major groups: the first with five species (two habitat generalists and three stream specialists) and the second composed by the other species (with different reproductive modes associated with flooded environments). The breeding period of most species was associated to the rainy season (October to February), and only Scinax hayii showed continuous breeding activity during the entire period of study.

Keywords: anuran amphibians; Atlantic Rainforest; diversity; breeding sites; spatial distribution; seasonal breeding patterns.

\section{Anurofauna do Parque Estadual Carlos Botelho - Núcleo Sete Barras, sudeste do Brasil: composição de espécies, uso de sítios reprodutivos e padrões sazonais de atividade reprodutiva}

Resumo: O objetivo deste trabalho foi estudar a composição de espécies, o uso de habitats reprodutivos e os padrões sazonais de atividade reprodutiva da anurofauna do Parque Estadual Carlos Botelho - Núcleo Sete Barras, estado de São Paulo, sudeste do Brasil. O trabalho de campo foi desenvolvido de setembro de 2005 a outubro de 2007 por meio de dois métodos principais: procura visual ativa no interior de uma parcela permanente de 10 ha e busca visual e acústica em sete habitats aquáticos de reprodução previamente selecionados. A riqueza de espécies foi relacionada com o esforço amostral por meio de curvas de acumulação de espécies e estimadores não-paramétricos. Foram registradas 33 espécies distribuídas em 12 famílias, 69\% das quais são endêmicas da Mata Atlântica. Trachycephalus mesophaeus representa um novo registro para o parque. Cycloramphus lutzorum está incluída como Deficiente em Dados na lista da IUCN. A curva de acumulação de espécie não se estabilizou, mostrando alguma tendência de crescimento. A similaridade no uso dos ambientes aquáticos por 20 espécies foi avaliada por meio de uma análise de agrupamento, que revelou dois grupos: o primeiro com cinco espécies (duas generalistas de habitat e três especialistas de riachos) e o segundo formado pelas demais espécies (com diferentes modos reprodutivos associados a ambientes aquáticos lênticos). O período reprodutivo da maioria das espécies esteve associado à estação chuvosa (outubro a março), e apenas Scinax hayii mostrou atividade reprodutiva contínua durante todo o período de estudo.

Palavras-chave: anfibios anuros; Floresta Atlâtica; diversidade; sítios reprodutivos; distribuição espacial; padrões reprodutivos sazonais. 


\section{Introduction}

The Atlantic Rainforest is home to 528 species of anurans, of which about $80 \%$ are endemic (Vancine et al. 2018). This astonishing diversity is commonly attributed to the highly rugged terrain and the existence of geographical barriers that isolate populations and create high levels of speciation and endemism; the stratified physiognomy of the vegetation, with a great diversity of epiphytes, together with high levels of rainfall and humidity, result in intense partitioning of habitats and microhabitats by anurans and the evolution of specialized reproductive modes (see Haddad \& Prado 2005 and references herein).

In the last decades many studies were developed on anuran amphibian communities from different physiognomies of the Atlantic Rainforest biome (e.g, Heyer et al. 1990, Canelas \& Bertoluci 2007, Araújo et al. 2010, Brassaloti et al. 2010, Forlani et al. 2010, Vilela et al. 2011, Figueiredo et al. 2019). Population declines and even local extinctions were detected in some localities, such as Santa Tereza, in Espírito Santo state (Weygoldt 1989), and Serra do Japi (Haddad \& Sazima 1992), Estação Biológica de Boracéia (Heyer et al. 1988, 1990, Bertoluci \& Heyer 1995, Verdade et al. 2011) and Estação Biológica do Alto da Serra de Paranapiacaba (Verdade et al. 2009), in São Paulo state, which show the importance of ecological studies, even in wellstudied regions, such as southeastern Brazil (Haddad \& Prado 2005, Brito 2008, Verdade et al. 2012).

The anuran fauna of the state of São Paulo is well known (about 230 species) and represents $27 \%$ of the Brazilian diversity and $4 \%$ of world diversity (Rossa-Feres et al. 2011). Most species are found in Atlantic Rainforest areas, including the Estação Biológica de Boracéia (66 espécies; Heyer et al. 1990; Verdade et al. 2011), the Parque Estadual Intervales (Bertoluci \& Rodrigues 2002b; 48 species), the Estação Biológica do Alto da Serra de Paranapiacaba (Verdade et al. 2009; 69 species), the Parque Estadual Turístico do Alto Ribeira - PETAR (Araújo et al. 2010; 60 species), and the Parque Natural Municipal Nascentes de Paranapiacaba (Trevine et al. 2014; 80 species).

The greatest diversity in São Paulo state was recorded in the Parque Estadual Carlos Botelho, with about 85 anuran species, which is perhaps due to the abundance of water bodies and the excellent state of conservation of this conservation area (e.g., Guix et al. 1994, 2000, Bertoluci et al. 2007, Forlani et al. 2010).

Spatial distribution and reproductive success of amphibians are strongly dependent on the physical characteristics of reproductive environments, varying in space and time. Environments with similar abiotic factors harbor different species compositions, which indicates that there is more than one factor influencing the choice of reproductive sites, such as habitat heterogeneity and degree of preservation of terrestrial habitats around aquatic breeding sites (Wells 1977, Gascon 1991, Rudolf \& Rödel 2005), which affect assemblage diversity, local abundance of some species and interspecific interactions (Underwood 2000).

Rainfall distribution and air temperature variation along the year strongly influence anuran breeding activity (Wells 2007). A higher number of species is able to reproduce throughout the year in aseasonal (Hero 1990, Gascon 1991) than in seasonal environments, where the calling and breeding activity of most species are associated with the rainy season (Aichinger 1987, Bertoluci 1998, Bertoluci \& Rodrigues 2002b, Canelas \& Bertoluci 2007, Narvaes et al. 2009).

The present study aimed to investigate the composition of the anuran fauna of the Núcleo Sete Barras of the Parque Estadual Carlos Botelho, São Paulo state, southeastern Brazil, the use of breeding sites by the species and their seasonal patterns of breeding activity.

\section{Materials and Methods}

\section{Study site}

The Parque Estadual Carlos Botelho (PECB) $\left(24^{\circ} 00^{\prime}-24^{\circ} 15^{\prime} \mathrm{S}\right.$, $\left.47^{\circ} 45^{\prime}-48^{\circ} 10^{\prime} \mathrm{W}\right)$ is part of an ecological complex of the Atlantic Rainforest in the southern part of the State of São Paulo, encompassing an area of approximately 38.000 ha, with altitudes that very between 30 to $1600 \mathrm{~m}$ above sea level, covered by Dense Ombrophylous Forest (Ferraz \& Varjabedian 1999) (Figure 1). According to Veloso et al. (1991), the vegetation at PECB may perform three different physiognomic and floristic compositions: montane rainforest, submontane and low lands. The Núcleo Sete Barras (NSB) comprises two forest formations (sub-montane and low lands) and is located in the municipality of Sete Barras, Vale do Ribeira de Iguape, in a contact zone between two geomorphological formations, Guapiara Plateau (low lands) and Serra de Paranapiacaba (sub-montane) (2411'37' S, 47055'11" W) (Ferraz \& Varjabedian 1999).

The climate is Cfa of Köppen, mesothermal, subtropical, hot and humid, with no dry season (Setzer 1946). In the study period, the mean annual temperature was $21.8^{\circ}$ and the annual accumulated precipitation was $1,582 \mathrm{~mm}$ (Bertoluci et al. 2007).

\section{Data sampling and collection}

The anuran fauna sampling was carried out using two main methods: active visual (Crump \& Scott 1994) in a $2500 \mathrm{~m}$ transect inside a permanent plot of 10 ha (more detail in Bertoluci et al. 2007a); and male vocal activity monitoring in seven different previously selected breeding habitats (Table 1). In the plot area, we carried out two visits a month between September 2005 and October 2006, always two researchers (20h/person), totalizing a sampling effort of $240 \mathrm{~h} /$ person. The breeding habitats were visited for two consecutive nights per month between September 2005 and October 2007, totaling 52 visits in the period. In addition, we recorded all individuals found by chance in the sampling areas. All selected reproductive habitats were located along the main track called "Trilha das Figueiras", which is located along the main road that connects the municipalities of São Miguel Arcanjo and Sete Barras (Figure 1).

Seasonal patterns of breeding activity were established by estimating the number of males (per species) calling synchronously at each aquatic site (Table 1) in the following classes of abundance: (1) 1-2, (2) 3-5, (3) 6-10, (4) 11-20, (5) 21-50, (6) more than 50 males (Bertoluci 1998, Bertoluci \& Rodrigues 2002b, Canelas \& Bertoluci 2007, Narvaes et al. 2009). The activity of species whose males did not vocalize in the selected sites was recorded in a qualitative way, and we considered the presence in the sites of gravid females, amplectant pairs, and egg clutches as evidences of actual reproduction, as already done 


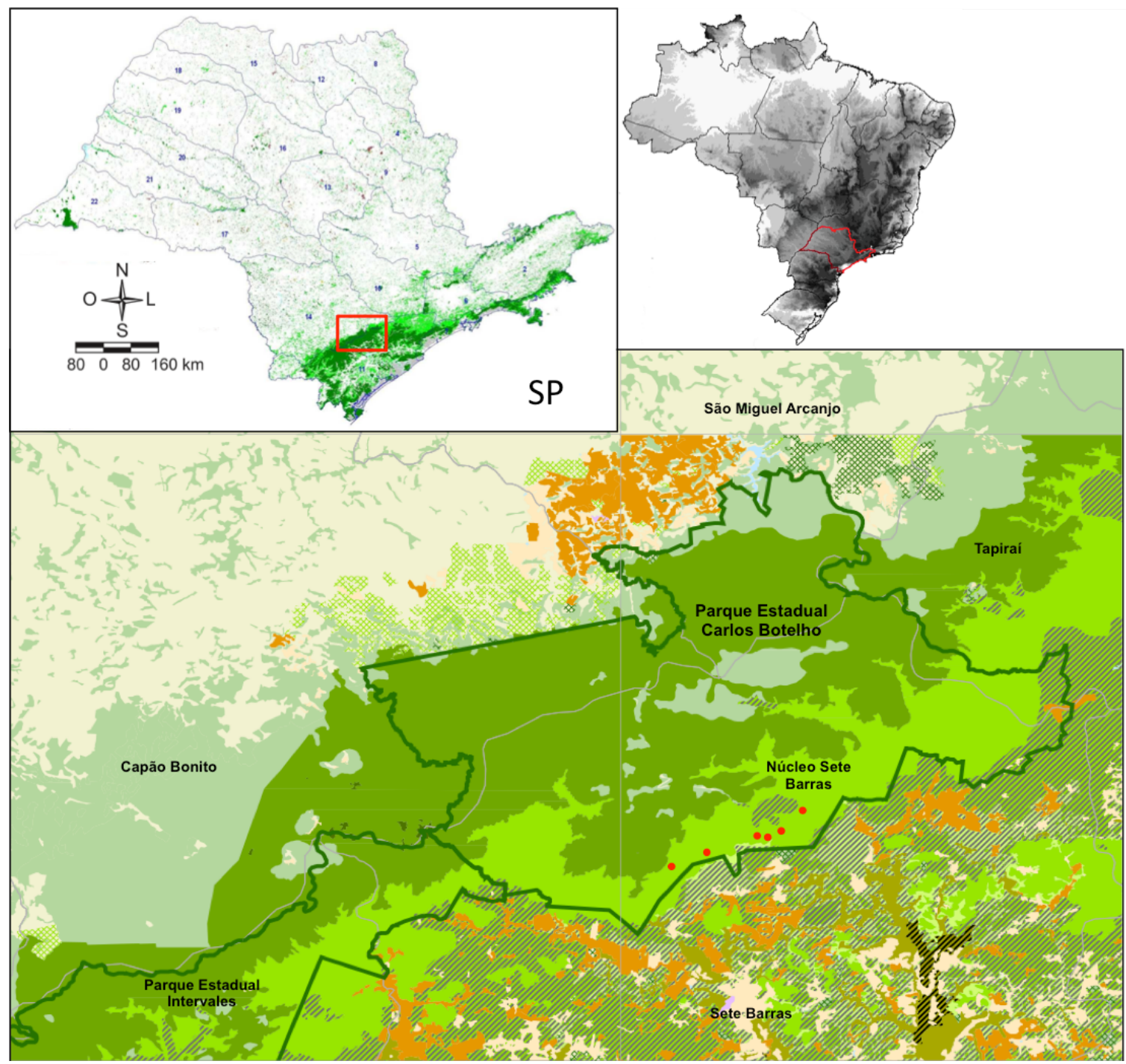

Figure 1. Geographical location of the study area showing the location of the sampled breeding sites $(\bullet)$.

Table 1. Physical characteristics of the seven water bodies studied in the Núcleo Sete Barras, Parque Estadual Carlos Botelho, southeastern Brazil. Legend: VAR - arboreal vegetation; VAT - understory bush vegetation; VHR - herbaceous vegetation (Poaceae); VHA - aquatic herbaceous vegetation. *Transect $100 \mathrm{~m}$.

\begin{tabular}{|c|c|c|c|c|c|c|}
\hline Sites & Geographic coordinates & Altitude (m) & Hydroperiod & Type & Substrate & Vegetation type \\
\hline $\mathrm{L} 2$ & $24^{\circ} 12^{\prime} 13^{\prime \prime} \mathrm{S}, 47^{\circ} 55^{\prime} 56^{\prime \prime} \mathrm{W}$ & 52 & Semipermanent & Pond & Muddy & VAR, VAT, VHA \\
\hline L3 & $24^{\circ} 12^{\prime} 08^{\prime \prime} \mathrm{S}, 47^{\circ} 56^{\prime} 30^{\prime \prime} \mathrm{W}$ & 44 & Permanent & Pond & Muddy & VAR, VAT, VHA \\
\hline L4 & $24^{\circ} 12^{\prime} 21^{\prime \prime} \mathrm{S}, 47^{\circ} 57^{\prime} 16^{\prime \prime} \mathrm{W}$ & 48 & Permanent & Pond & Muddy & VAR, VAT, VHA \\
\hline L5 & $24^{\circ} 11^{\prime} 37^{\prime \prime} \mathrm{S}, 47^{\circ} 55^{\prime} 11^{\prime \prime} \mathrm{W}$ & 65 & Permanent & Reservoir & Argiloso & VAT, VHR \\
\hline $\mathrm{R} 2$ & $24^{\circ} 11^{\prime} 39^{\prime \prime} \mathrm{S}, 47^{\circ} 55^{\prime} 55^{\prime \prime} \mathrm{W}$ & 48 & Temporary & Stream* & Muddy & VAR, VAT, VHA \\
\hline
\end{tabular}


by Bertoluci (1998), Bertoluci and Rodrigues (2002b), and Canelas \& Bertoluci (2007).

Some individuals were collected and submitted to a saturate atmosphere of $\mathrm{CO}_{2}$ (resolution $\mathrm{N}^{\circ} 714$ of 20 June 2002 of CFMV), fixed in formal 10\% and preserved in alcohol $70 \%$ (under license IBAMA $\mathrm{n}^{\circ}$ 430/05). Voucher specimens were deposited in the herpetological collection of Escola Superior de Agricultura Luiz de Queiroz, Universidade de São Paulo (Appendix I).

\section{Data analysis}

The species richness registered in relation to the sampling effort was assessed by the species accumulation curve (sensu Colwell et al. 2004), calculated through the exact method (Kindt 2004) using the function "specaccum". To estimate the richness we used the function "specpool" and "poolaccum" and the non-parametric estimators Bootstrap and Jacknife $I$ (Santos 2003) with 10,000 randomizations with sample reposition, "vegan" package (Oksanen et al. 2011), developed for R environment (R Development Core Team 2012). A matrix with monthly occurrence was used for all species registered in the reproductive habitats and chance encounters.

To evaluate the similarity in the use of the breeding sites, we considered only species that show reproductive activity in the selected aquatic sites between September 2006 and October 2007. Based on the breeding sites use, species were classified as habitat generalists and specialists. Dissimilarity between species pairs was also calculated by the complement of the Jaccard index (DJ = 1- J), and this triangular matrix was submitted to a cluster analysis by the UPGMA method (e.g., Sneath \& Sokal 1973), which calculates the coefficient of cofenetic correlation ( $r$ ), indicating the degree of representativeness of the similarity matrix in the dendrogram, so that values of $r \geq 0.8$ allow to consider that the dendrogram adequately represents the dissimilarity matrix (Rohlf 2000). For this analysis we use the "hclust" function, applying the "average" method, also from the "vegan" package (Oksanen et al. 2011), developed for the R-environment (R Development Core Team 2012).

\section{Results}

\section{Species composition}

During the study period we recorded to the NSB 33 species distributed in 12 families: Brachycephalidae (1 species), Bufonidae (4), Centrolenidae (1), Craugastoridae (1), Cycloramphidae (1), Hemiphractidae (1), Hylidae (15), Hylodidae (1), Leptodactylidae (5), Microhylidae (1), Odontophrynidae (1), and Phyllomedusidae (1) (Table 2, Figure 2). Trachycephalus mesophaeus represents a new record to the area. The species accumulation curve did not show stabilization (Figure 3), with certain trend towards ascension, which is evident by the high confidence interval. The Jackknife estimator I, based in the rare species occurrence, showed higher value in the last month of our sampling $\left(\mathrm{S}_{\mathrm{J}}=35.88 \pm 1.665\right.$ standard error), and the Bootstrap estimator, considering the full data set (repeated sampling with reposition), for 10000 randomization, was $\mathrm{S}_{\mathrm{B}}=34.34 \pm 1.004$ (Figure 4).

\section{Use of breeding sites}

Twenty species were recorded in the seven breeding sites we monitored (Table 3). The number of species in the sites varied from four to 12. Site L1 showed the highest number of species (12), followed by Site L2 (11). The lowest number of species was found in Site R2 (4), the only temporary site studied. Fritziana fissilis, Dendrophryniscus brevipollicatus and Physalaemus spiniger were recorded in the surroundings of water bodies. Cluster analysis identified two major groups: (I) formed by Rhinella ornata and R. icterica (Ia) and Cycloramphus lutzorum, Vitreorana uranoscopa and Bokermannohyla hylax (Ib); (II) formed by the four species of Dendropsophus (IIa) and other species (IIb) (Figure 5).

\section{Seasonal breeding patterns}

Table 4 summarizes the annual breeding patterns of the 20 anuran species whose males vocalized in the seven aquatic sites showed in Table 3. Classes shown here are the highest classes of the number of calling males recorded each month considering all monitoring sessions and all sites. Evidences of actual reproduction (amplectant pairs, oviposition behavior or egg clusters) are indicated. Anurans called in almost every month of the two-years period, with higher number of active species (more than 10) being recorded in the rainy seasons (October to February) of both years. Only Scinax hayii displayed a continuous breeding pattern, with males calling in 22 of the 24 samples.

\section{Discussion}

\section{Species composition}

The species composition at the NSB is typical of Neotropical sites, with high representativeness of Hylidae (Duellman 1999). In addition, $69 \%$ of the species are endemic to the Atlantic Rainforest; the high degree of endemism is also typical of this biome (Vancine et al. 2018), however the geomorphological characteristics of NSB, with altitudes close to the sea level, rising in a gradient that reaches 1,000 $\mathrm{m}$ in altitude, influenced the composition of the anuran fauna, which is composed by species typical of the low Atlantic Rainforest (Rhinella hoogmoedi, Ololygon argyreornata and O. littoralis) (Pombal \& Gordo 1991, Caramaschi \& Pombal 2006, Bertoluci et al. 2007) alongside of species restricted to the hillside forest (e.g., Ischnocnema aff. guentheri) (Bertoluci et al. 2007).

The estimated richness values theoretically indicate the possibility of increasing at least three species in the sampling survey, which can be observed when considering the high $\beta$ diversity of anuran fauna found in PECB in its different phytophysiognomies or even in an altitudinal gradient (e.g. Guix et al. 1994, Guix et al. 2000, Bertoluci et al. 2007, Moraes et al. 2007, Forlani et al. 2010).

The anuran fauna of different portions of PECB was described in four other studies (Guix et al., 1994; Guix et al., 2000; Bertoluci et al., 2007; Forlani et al., 2010). The compilation of these lists by Forlani et al. (2010) resulted in a richness of 85 species for the entire park. We add here one species to that list, Trachycephalus mesophaeus, maybe due to our higher sampling effort compared to those of the studies cited 
Table 2. Anuran species recorded in the Núcleo Sete Barras, Parque Estadual Carlos Botelho, southeastern Brazil, between September 2005 and October 2007.

\begin{tabular}{|c|c|}
\hline \multirow{5}{*}{$\begin{array}{c}\text { Brachycephalidae } \\
\text { Bufonidae }\end{array}$} & Ischnocnema aff. guentheri (Steindachner, 1864) \\
\hline & Dendrophryniscus brevipollicatus Jiménez de la Espada, 18701871 "1870" \\
\hline & Rhinella hoogmoedi Caramaschi \& Pombal, 2006 \\
\hline & Rhinella icterica (Spix, 1824) \\
\hline & Rhinella ornata (Spix, 1824) \\
\hline Centrolenidae & Vitreorana uranoscopa (Müller, 1924) \\
\hline Craugastoridae & Haddadus binotatus (Spix, 1824) \\
\hline Cycloramphidae & Cycloramphus lutzorum Heyer, 1983 \\
\hline Hemiphractidae & Fritziana fissilis (Miranda Ribeiro, 1920) \\
\hline \multirow[t]{15}{*}{ Hylidae } & Boana albomarginata (Spix, 1824) \\
\hline & Boana bischoffi (Boulenger, 1887) \\
\hline & Boana faber (Wied-Neuwied, 1821) \\
\hline & Boana semilineata (Spix, 1824) \\
\hline & Bokermannohyla hylax (Heyer, 1985) \\
\hline & Dendropsophus berthalutzae (Bokermann, 1962) \\
\hline & Dendropsophus elegans (Wied-Neuwied, 1824) \\
\hline & Dendropsophus minutus (Peters, 1872) \\
\hline & Dendropsophus seniculus (Cope, 1868) \\
\hline & Ololygon argyreornata (Miranda-Ribeiro, 1926) \\
\hline & Ololygon littoralis (Pombal \& Gordo, 1991) \\
\hline & Ololygon rizibilis (Bokermann, 1964) \\
\hline & Scinax aff. alter (B. Lutz, 1973) \\
\hline & Scinax hayii (Barbour, 1909) \\
\hline & Trachycephalus mesophaeus (Hensel, 1867) \\
\hline Hylodidae & Hylodes cf. phyllodes \\
\hline \multirow[t]{5}{*}{ Leptodactylidae } & Adenomera marmorata Steindachner, 1867 \\
\hline & Leptodactylus latrans (Steffen, 1815) \\
\hline & Leptodactylus notoaktites Heyer, 1978 \\
\hline & Physalaemus olfersii (Lichtenstein \& Martens, 1856) \\
\hline & Physalaemus spiniger (Miranda-Ribeiro, 1926) \\
\hline Microhylidae & Myersiella microps (Duméril \& Bibron, 1841) \\
\hline Odontophrynidae & Proceratophrys boiei (Wied-Neuwied, 1825) \\
\hline Phyllomedusidae & Phyllomedusa distincta A. Lutz in B. Lutz, 1950 \\
\hline
\end{tabular}

above, raising the overall richness of PECB to 86 species. This richness corresponds to $37 \%$ of the anuran known for the state of São Paulo (Rossa-Feres et al. 2011). As expected the composition of the anuran fauna of NSB is similar to those of other localities of southeastern Brazil covered by the Dense Ombrophilous Forest of São Paulo state (Bertoluci et al. 2007), like the Estação Biológica de Boracéia (Heyer et al., 1990; Bertoluci et al., 2005), the Parque Estadual Intervales (Bertoluci, 1998), and the Reserva Biológica do Alto da Serra de Paranapiacaba (Verdade et al. 2009). The different physiognomies of the Atlantic Forest, the large altitudinal gradient (Guix et al. 1994, 2000) and the good state of conservation of PECB areas, and habitat heterogeneity (e.g., Silva et al. 2011 and references therein) are also relevant factors in the interpretation of this high richness.

Although none of the species recorded in the present study were included in the Brazilian red list of endangered fauna, Cycloramphus lutzorum is considered Data Deficient with decreasing populations by IUCN (2019); major threats to this frog are residential and commercial development, agriculture and aquaculture, and biological resource use.

\section{Breeding site utilization}

Species that used the monitored reproductive habitats did not distribute homogeneously among sites. Rhinella ornata, R. icterica and Ololygon littoralis were classified as habitat generalists (they used all habitat types); the pattern of habitat use of these species has already been observed in other taxocenoses (e.g., Izecksohn \& Carvalho-e-Silva 2001, Bertoluci \& Rodrigues 2002c, Narvaes et al. 2009).

Vitreorana uranoscopa, Cycloramphus lutzorum and Bokermannohyla hylax were considered stream specialists. Vitreorana uranoscopa lays eggs on leaves of the marginal vegetation suspended over streams, where eggs fall and tadpoles complete development to 


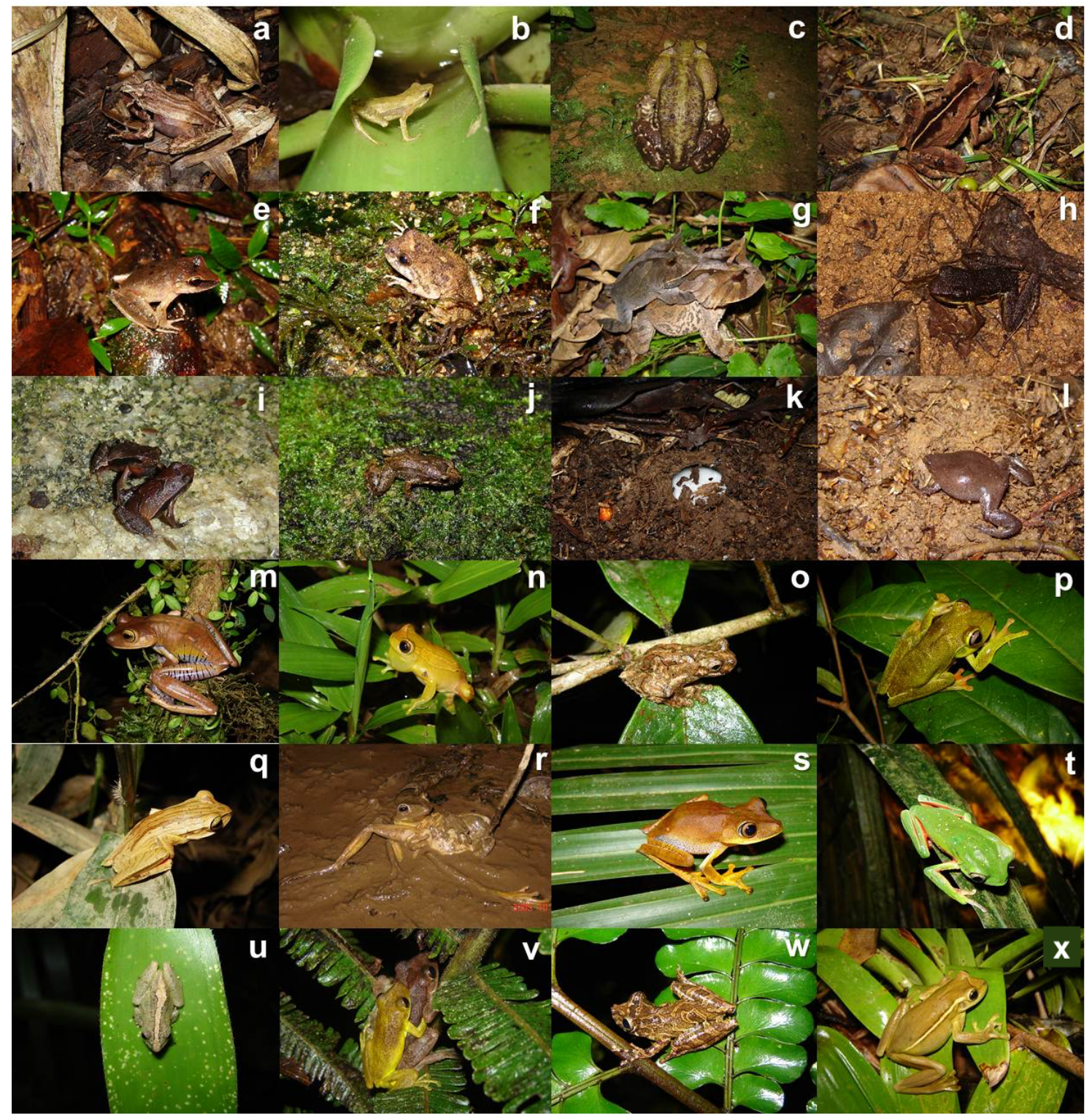

Figure 2. Anuran species recorded in the Núcleo Sete Barras (PECB): (a) Ischnocnema aff. guentheri, (b) Dendrophryniscus brevipollicatus, (c) Rhinella icterica, (d) Rhinella ornata, (e) Haddadus binotatus, (f) Cycloramphus lutzorum, (g) Proceratophrys boiei, amplectant pair, (h) Hylodes cf. phyllodes, (i) Physalaemus spiniger, (j) Adenomera marmorata, (k) spawn of A. marmorata, (1) Myersiella microps, (m) Bokermannohyla hylax, (n) Dendropsophus elegans, (o) Dendropsophus seniculus, (p) Boana albomarginata, (q) Boana bischoffi, (r) fighting males of Boana faber, (s) Boana semilineata, (t) Phyllomedusa distincta, (u) Scinax aff. alter, (v) Scinax hayii, amplectant pair, (w) Ololygon littoralis, (x) Trachycephalus mesophaeus.

metamorphosis (Heyer 1985a, 1990). Cycloramphus species lay their eggs on rocks and in wet rock crevices, with semi-terrestrial tadpoles living at the water-land interface, microhabitats commonly found on the banks of rocky streams (Haddad \& Prado 2005), as sampled in PECB. Bokermannohyla hylax is a typical species of dense ombrophilous forest streams (Heyer 1985b; Bertoluci 2002; Bertoluci et al. 2003). Males vocalize from the vegetation on the edge of forest streams, tadpoles seek shelter under rocks, dead leaves or burrow into the mud (Bertoluci et al. 2003). The presence of this species in Site L1 (classified as a pond) is probably due to the interruption of the stream course by the road slope, altering the original structure of the habitat. Changes caused by anthropogenic disturbances modify the local structure of the forest, form new microhabitats and make different resources available, which influences community structure (Connell \& Slatyer 1977, Pickett \& White 1985, Tocher et al. 2001).

Species of the genus Rhinella were considered habitat generalists, showing the primitive reproductive mode for the group, which favors the exploration of different habitat types (Haddad \& Prado 2005). Subgroup Ib of the dendrogram includes only species with specialized reproductive modes associated with streams (Heyer et al. 1990, Bertoluci et al. 2004, 


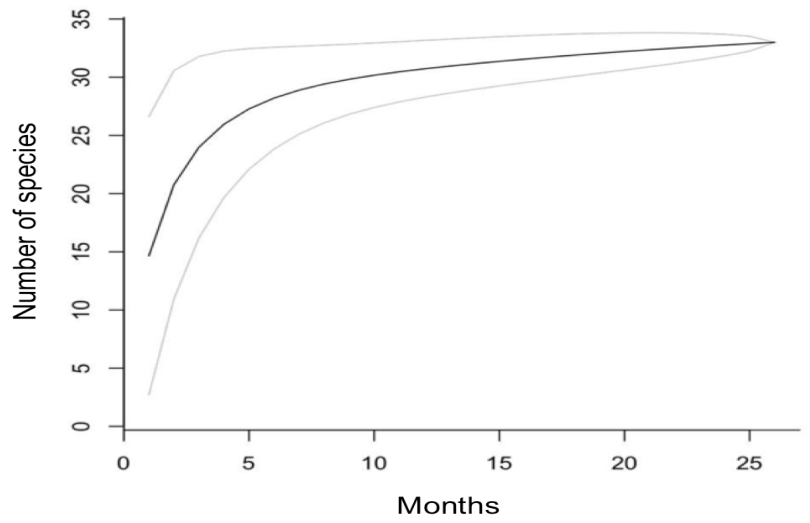

Figure 3. Species accumulation curve between September 2005 and October 2007.

Haddad \& Prado 2005). Group II includes only species that breed in lentic water bodies, all of the family Hylidae, except Leptodactylus latrans (Leptodactylidae). In subgroup IIa are Dendropsophus species, typical of lagoons (e.g., Bertoluci \& Rodrigues 2002c, Narvaes et al. 2009) and with generalized reproductive mode (e.g., Haddad \& Prado 2005). In subgroup IIb there are two smaller branches; the former includes all species of Scinaxinae (Scinax and Ololygon), as well as Leptodactylus latrans and Phyllomedusa distincta, pond-associated species. Among the species of Scinax all have generalized reproductive mode except Ololygon rizibilis, which produces an aquatic foam nest
(Haddad \& Prado 2005). Leptodactylus latrans builds floating foam nests in permanent or semipermanent environments (Vaz-Ferreira \& Gerhau 1975) and $P$. distincta lays eggs on leaves hanging over water in permanent aquatic environments (Woehl \& Woehl 2000). The most intimate grouping between $O$. rizibilis and $L$. latrans may be due to the use of semi-permanent environments, suitable for their specialized reproductive mode. The second branch is formed by all Boana species, among which only Boana faber has a specialized reproductive mode (eggs in nests dug in mud in the banks of lentic water bodies; Martins \& Haddad 1988), despite being habitat generalist.

The high degree of overlap in the use of reproductive habitats corroborates the well-established idea that suitable water bodies for reproduction behave as limiting factors for anurans (e.g., Bertoluci \& Rodrigues 2002c). However habitat heterogeneity permits anurans use specific microhabitats as calling, oviposition and developmental sites with low or no overlap, influencing anuran richness and the composition of the assemblages (e.g., Bertoluci \& Rodrigues 2002c, Vasconcelos \& Rossa-Feres 2008, Vasconcelos et al. 2009, Figueiredo et al. 2019).

\section{Seasonal patterns of breeding activity}

The breeding activity of anurans at PECB-NSB was closely related to the rainy season. This general pattern is commonly found in seasonal tropical areas of both Amazonia (Toft \& Duellman 1979, Aichinger, 1987, Hero, 1990, Gascon 1991, Duellman, 1995) and southeastern Brazil (Bertoluci 1998, Eterovick \& Sazima 2000, Bertoluci \& Rodrigues 2002b, Canelas \& Bertoluci 2007, Narvaes et al. 2009). Only

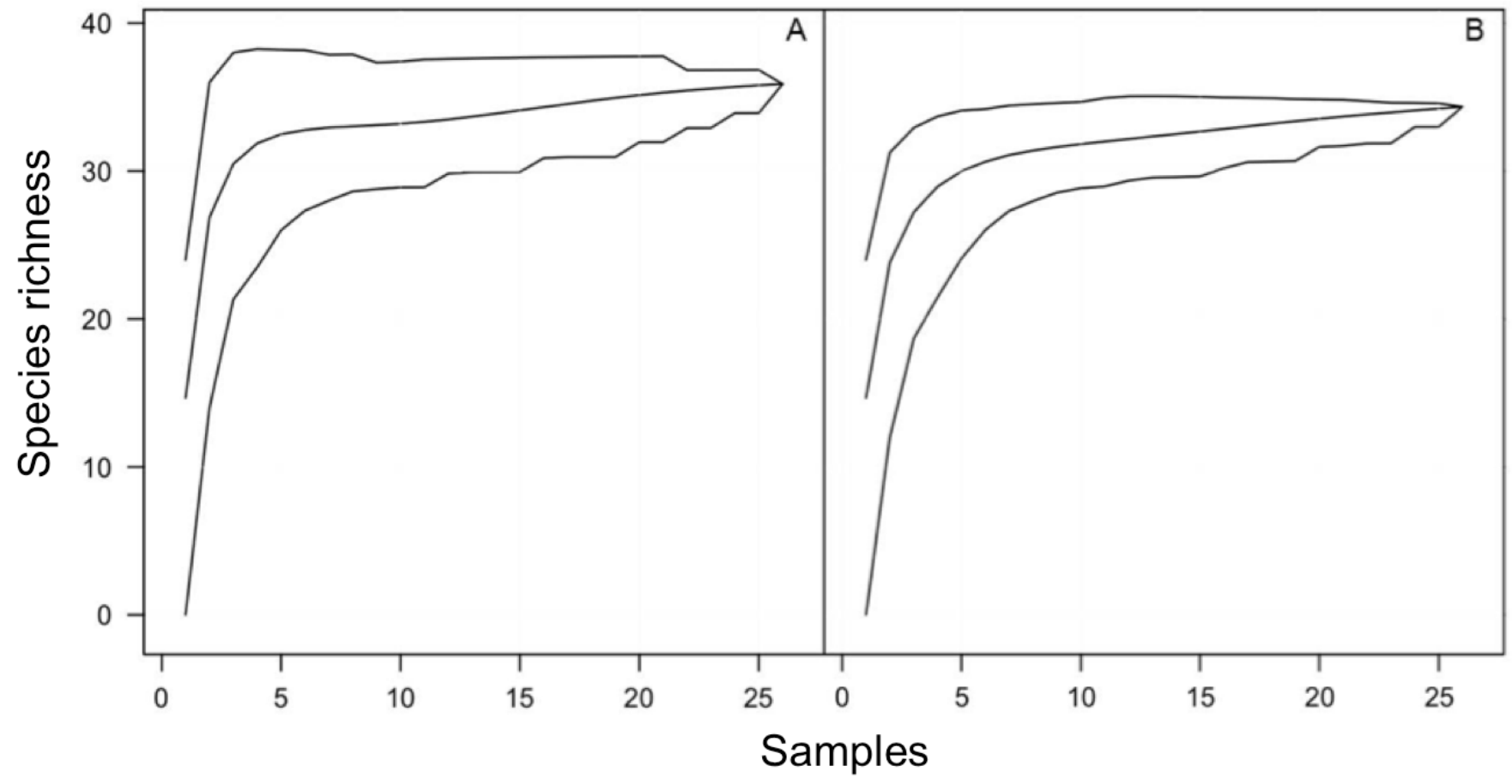

Figure 4. Richness estimators $(A)$ Bootstrap $(\mathrm{SB}=32.53)$ and $(B)$ Jacknife $I(\mathrm{SJ}=35.88 \pm 1.665$ standard error) built from 10,000 randomizations, during 26 months (September 2005 to October 2007). 
Bertoluci J. et al.

Table 3. Distribution of 20 anuran species in seven aquatic breeding sites of the Núcleo Sete Barras, Parque Estadual Carlos Botelho, southeastern Brazil.

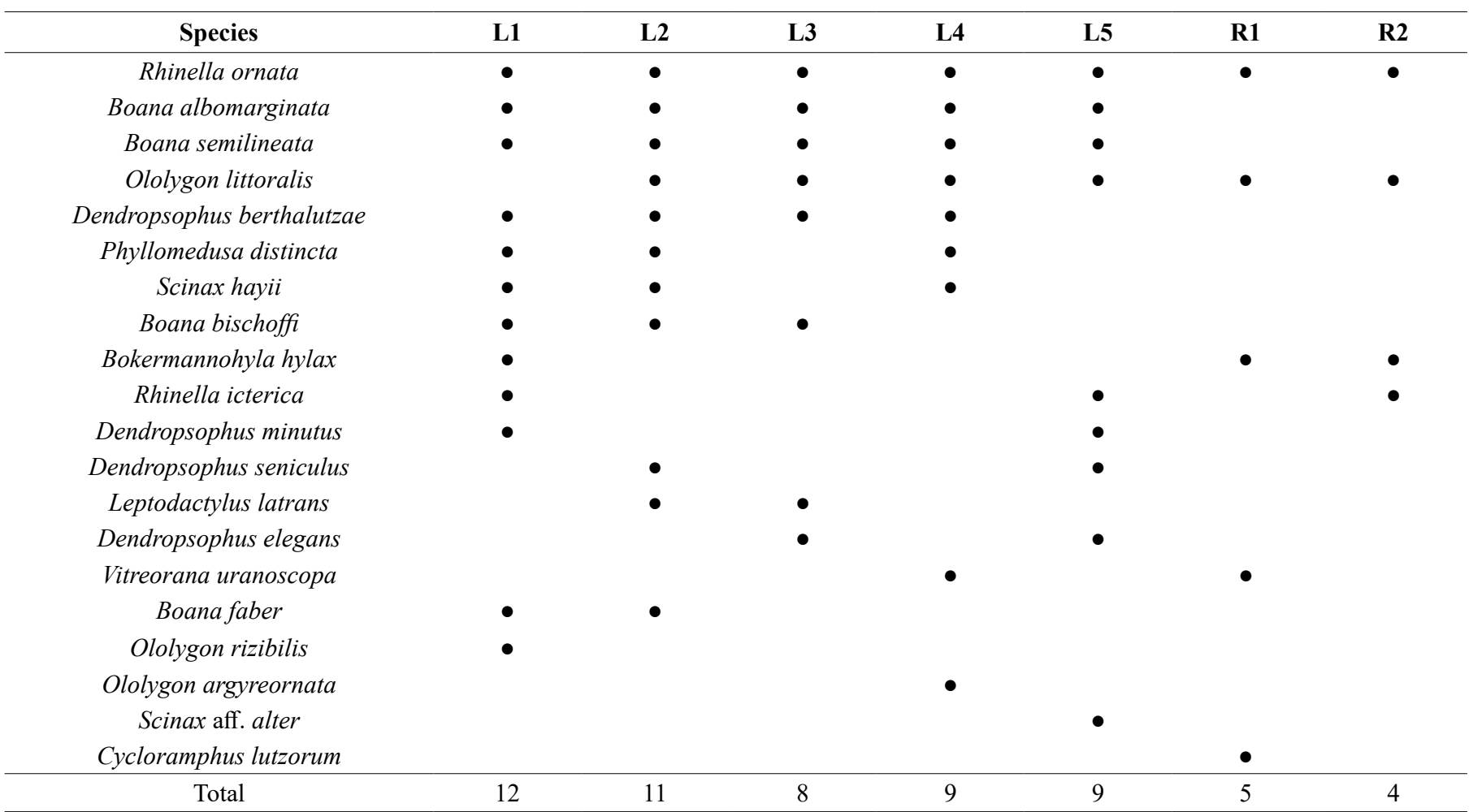

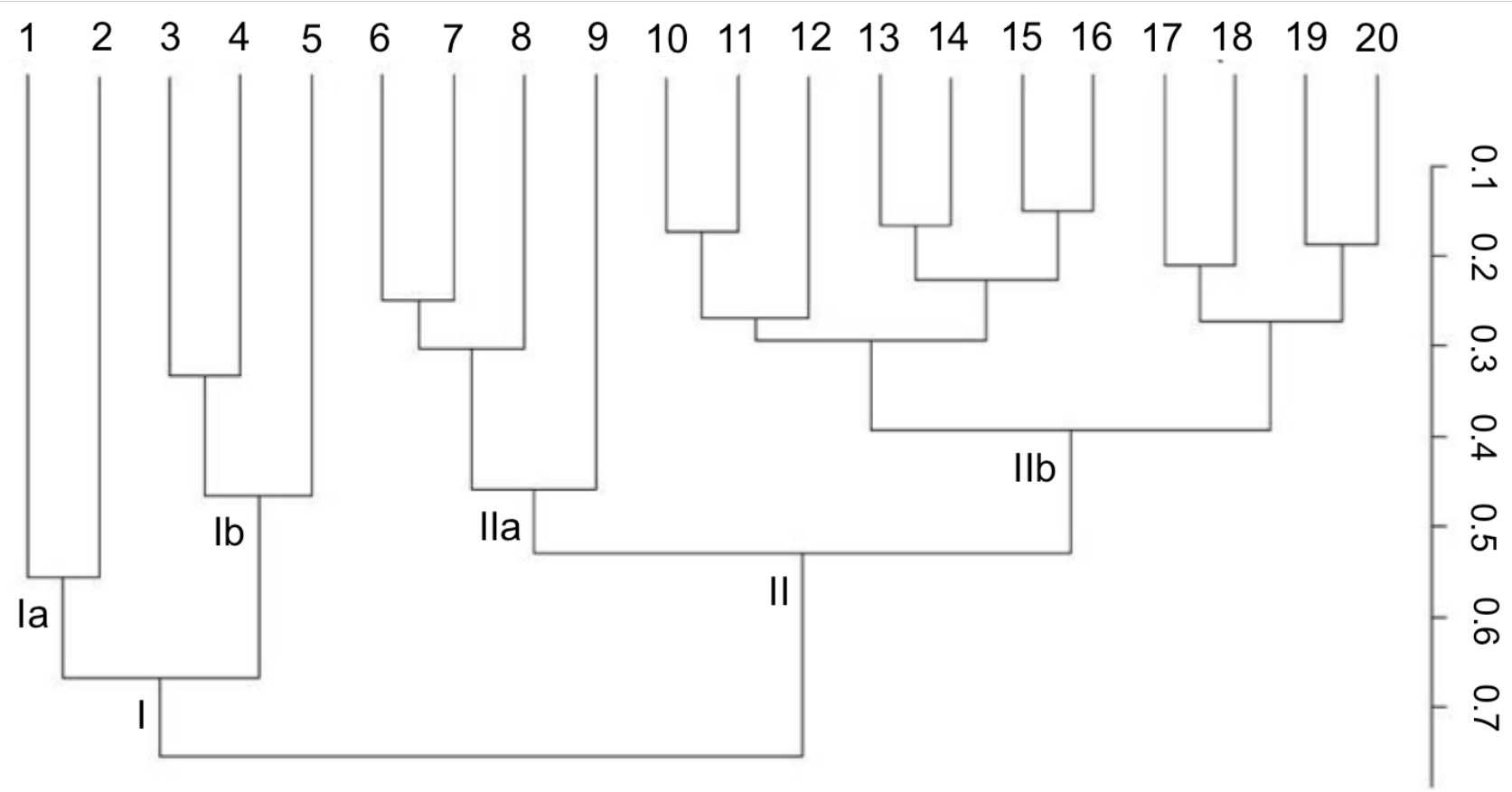

Figure 5. Cluster analyses of 20 anuran species based on their occurrence in seven breeding sites of the Núcleo Sete Barras-Parque Estadual Carlos Botelho (SP). (1) Rhinella ornata, (2) R. icterica, (3) Cycloramphus lutzorum, (4) Vitreorana uranoscopa, (5) Bokermannohyla hylax, (6) Dendropsophus seniculus, (7) D. minutus, (8) D. elegans, (9) D. berthalutzae, (10) Leptodactylus latrans, (11) Ololygon rizibilis, (12) O. littoralis, (13) O. argyreornata, (14) Scinax alter, (15) S. hayii, (16) Phyllomedusa distincta, (17) Boana semilineata, (18) B. albomarginata, (19) B. faber, (20) B. bischoffi. 


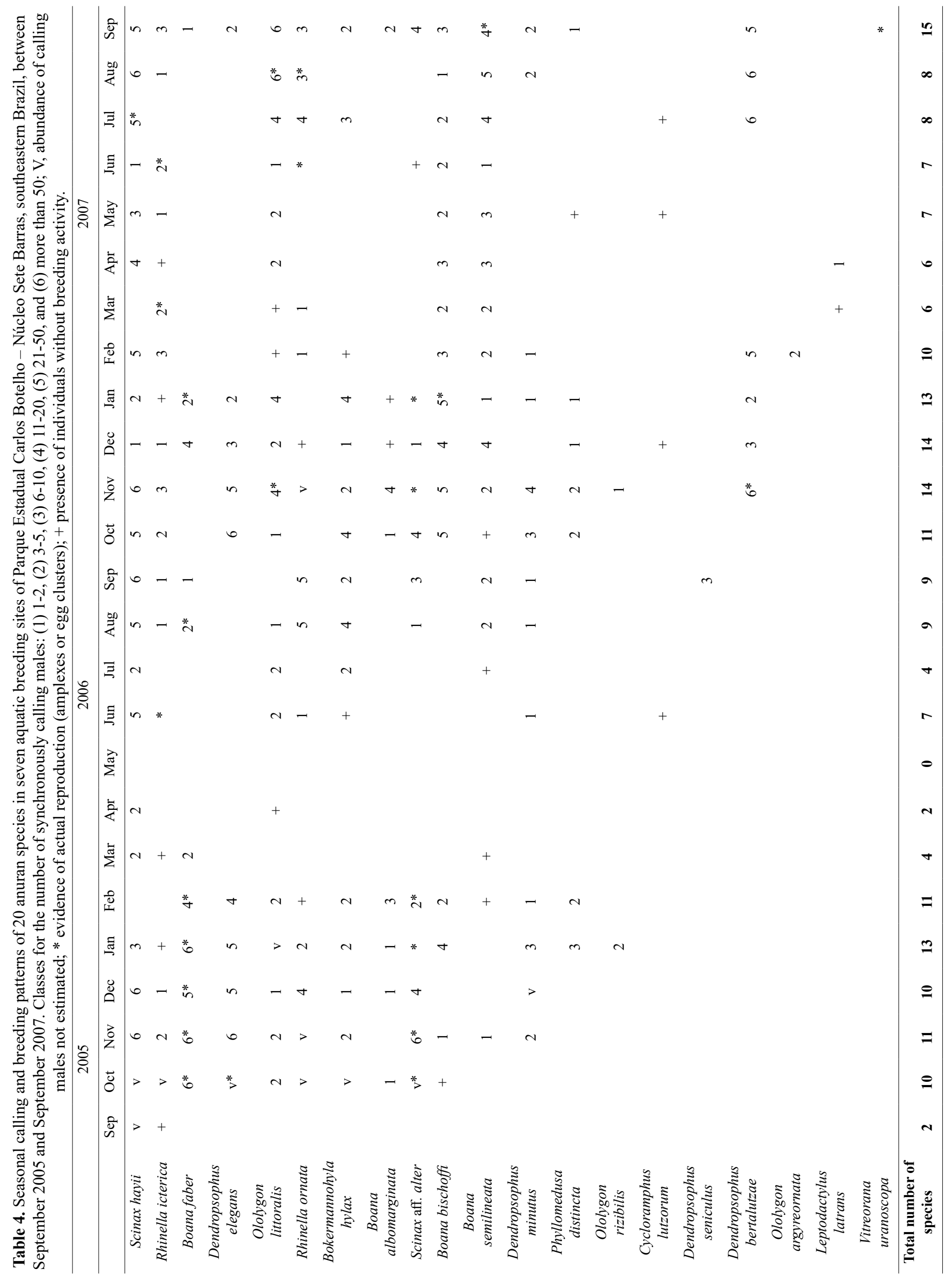


Scinax hayii showed calling activity almost throughout the entire period of study (22/24 months), a continuous breeding pattern already observed in the populations of the Estação Biológica de Boracéia (Ombrophylous forest; Bertoluci \& Rodrigues 2002b) and Estação Ecológica JuréiaItatins (Restinga forest; Narvaes et al. 2009), both sites located is São Paulo state, southeastern Brazil. A breeding pattern associate to the rainy season was showed by $S$. hayii in the Parque Estadual Intervales (Ombrophylous forest, Bertoluci 1998), also in São Paulo state. These differences seems to be related to the different climate regimes of these localities. A high proportion of continuous breeders is characteristic of aseasonal environments (e.g. Crump 1974).

We conclude claiming attention to the importance of preserving all types of habitats and microhabitats in the entire altitudinal gradient of PECB as a strategy for the conservation of frogs of southeastern Brazil, one of the richest regions of the world.

\section{Supplementary Material}

The following online material is available for this article:

Appendix I - Voucher material.

\section{Acknowledgements}

Authors are grateful to FAPESP for the financial support (process 04/15938-5 and 99/09635-0); to Vanessa K. Verdade for help with the identification of some species; to Hussan Zaher for the access to the herpetological collection at the MZUSP; to IBAMA for the collection license (number 430/05); to José Luiz Camargo Maia, director of the Parque Estadual Carlos Botelho, for the permission to access the park and logistical support; to Gabriel L. Brejão, Pablo G. Soares and Thiago Portelinha for the help in the field work; to Célio Haddad for the access to the anuran collection at the CFBH (UNESP). JB is a researcher of CNPq (process number 309017/2016-5).

\section{Author Contributions}

Jaime Bertoluci: Substantial contribution in the conception and design of the work; Contribution in the acquisition of data; Contribution in the analysis and interpretation of data; Contribution in the writing of the work; Contribution in the critical review adding intellectual content.

Henrique Oliveira Sawakuchi: Substantial contribution in the conception and design of the work; Contribution in the acquisition of data; Contribution in the analysis and interpretation of data; Contribution in the writing of the work; Contribution in the critical revision adding intellectual content.

Carolina Ortiz: Contribution in the analysis and interpretation of data; Contribution in the writing of the work.

Ricardo Augusto Brassaloti: Substantial contribution in the conception and design of the work; Contribution in the acquisition of data; Contribution in the analysis and interpretation of data; Contribution in the writing of the work; Contribution in the critical review adding intellectual content.

José Wagner Ribeiro-Júnior: Contribution to data acquisition; Contribution to the writing of the work.

Shirley Famelli: Contribution on data acquisition; Contribution on data analysis and interpretation; Contribution to the writing.of the work

\section{Conflicts of interest}

The authors declare that they have no conflict of interest related to the publication of this manuscript.

\section{Ethics}

Permits necessary to this study in the time it was developed were collection license from IBAMA and license to study in conservation units (COTEC). We had these two licenses.

\section{Data availability}

Results from this study should be stored in the Sistema de Informação Ambiental do Programa Biota/Fapesp/SinBiota, since it was part of Programa Biota SP.

\section{References}

AICHINGER, M. 1987. Annual activity patterns of anurans in a seasonal Neotropical environment. Oecologia 71(4):583-592.

ARAUJO, C.O., CONDEZ, T.H., BOVO, R.P., CENTENO, F.C. \& LUIZ, A.M. 2010. Amphibians and reptiles of the Parque Estadual Turístico do Alto Ribeira (PETAR), SP: an Atlantic Forest remnant of Southeastern Brazil. Biota Neotropica. 10(4):257-274. https://doi.org/10.1590/S167606032010000400031 (last access on 08/10/2020.

BERTOLUCI, J. \& HEYER, W.R. 1995. Boracéia update. Froglog 14:2-3.

BERTOLUCI, J. 1998. Annual patterns of breeding activity in Atlantic Rainforest anurans. J. Herpetol. 32(4):607-611.

BERTOLUCI, J. 2002. Diel activity of the tadpoles of Hyla hylax (Anura, Hylidae) at Boracéia, southeastern Brazil. Phyllomedusa 1(1):41-43.

BERTOLUCI, J. \& RODRIGUES, M.T. 2002a. Utilização de hábitats reprodutivos e micro-hábitats de vocalização em uma taxocenose de anuros (Amphibia) da Mata Atlântica do sudeste do Brasil. Pap. Avul. Zool. 42(11):287-297.

BERTOLUCI, J. \& RODRIGUES, M.T. 2002b. Seasonal patterns of breeding activity of Atlantic rainforest anurans at Boracéia, Southeastern Brazil. Amphibia-Reptilia 23(2):161-167.

BERTOLUCI, J., XAVIER, V. \& CASSIMIRO, J. 2003. Description of the tadpole of Hyla hylax Heyer, 1985 (Anura, Hylidae) with notes on its ecology. Amphibia-Reptilia 24:509-514.

BERTOLUCI, J., BRASSALOTI, R.A., RIBEIRO-JR, J.W., VILELA, V.M.F.N. \& SAWAKUCHI, H.O. 2007. Species composition and similarities among anuran assemblages of forest sites in southeastern Brazil. Sci. Agric. 64(4):364-374.

BERTOLUCI, J., VERDADE, V.K., RODRIGUES, M.T., PAVAN, D., LIOU, N. \& LANGE, M.C. 2005. Anuros da Estação Biológica de Boracéia (EBB): 25 anos após declínios. In: Resumos do Congresso Brasileiro de Herpetologia. Belo Horizonte.

BRASSALOTI, R.A., ROSSA-FERES, D. C. \& BERTOLUCI, J. 2010 Anurofauna da Floresta Estacional Semidecidual da Estação Ecológica dos Caetetus, Sudeste do Brasil. Biota Neotropica. 10(1):275-292. https:// doi.org/10.1590/S1676-06032010000100024 (last access on 08/10/2020).

BRITO, D. 2008. Amphibian Conservation: Are we on the right track? Biological Conservation 141:2912-2917.

CANELAS, M.A.S. \& BERTOLUCI, J. 2007. Anurans of the Serra do Caraça, southeastern Brazil: species composition and phenological patterns of calling activity. Iheringia, Sér. Zool. 97(1):21-26,

CARAMASCHI, U. \& POMBAL, J.P.JR. 2006. A new species of Rhinella Fitzinger, 1826 from the Atlantic Rain Forest, eastern Brazil (Amphibia, Anura, Bufonidae). Pap. Avul. Zool. 46: 251-259. 
COLWELL, R.K., MAO, C.X. \& CHANG, J. 2004. Interpolating, extrapolating, and comparing incidence-based species accumulation curves. Ecology 85(10):2717-2727.

CONNEL, J.H. \& SLATYER, R.O. 1977.Mechanisms of sucession in natural comunities and their role in community stability and organization. Am. Nat. 111: $1119-1144$

CRUMP, M.L. 1974. Reproductive strategies in a tropical anuran community. Miscellaneous Publications of the Museum of Natural History of the University of Kansas 61:1-68.

CRUMP, M.L. \& SCOTT JR., N.J. 1994. Standard techniques for inventory and monitoring: Visual encounter surveys. In Measuring and Monitoring Biological Diversity - Standard Methods for Amphibians (W.R. Heyer, M.A. Donnelly, R.W. McDiarmid, L.A.C. Hayek \& M.S. Foster, eds.). Smithsonian Institution Press, Washington, p.84-92.

DUELLMAN, W.E. 1999. Distribution patterns of amphibians in the South America, In Patterns of Distribution of Amphibians - A Global Perspective (W. E. Duellman, ed.). Johns Hopkins University Press, Baltimore and London, p.255-327.

FERRAZ, L.P.M. \& VARJABEDIAN, R. 1999. Evolução histórica da implantação e consolidação das informações disponíveis sobre o Parque Estadual Carlos Botelho. Secretaria do Meio Ambiente/ Instituto Florestal, São Paulo.

FIGUEIREDO, G.T., STORTI, L.F., LOURENÇO-DE-MORAES, R., SHIBATTA, O.A. \& ANJOS, L. 2019. Influence of microhabitat on the richness of anuran species: a case study of different landscapes in the Atlantic Forest of southern Brazil. An. Acad. Bras. Ciênc. 91(2): e20171023.

FORLANI, M.C., BERNARDO, P. H., HADDAD, C. F. B. \& ZAHER. H. 2010. Herpetofauna do Parque Estadual Carlos Botelho, São Paulo, Brasil. Biota Neotropica. 10(3):265-309. https://doi.org/10.1590/ S1676-06032010000300028 (last access on 08/10/2020). http://www. biotaneotropica.org.br/v7n2/pt/abstract?article+bn00307022007.

GASCON, C. 1991. Population- and community-level analyses of species occurrences of central amazonian rainforest tadpoles. Ecology 72(5):17311746.

GUIX, J.C.; NUNES, V.S.; MIRANDA, J.R. 1994. Autochthonous and colonizing species of frogs in Carlos Botelho State Reserve, southeastern Brazil. Bol. Asoc. Herpetol. Esp. 5(1):8-13.

GUIX, J.C.; LLORENTE, G.; MONTORI, A.; CARRETERO, M.A.; SANTOS, X. 2000. Una nueva área de elevada riqueza de anuros em El Bosque Lluvioso Atlántico de Brasil. Bol. Asoc. Herpetol. Esp. 11(2):100-105.

HADDAD, C.F.B. \& PRADO, C.P.A. 2005. Reproductive modes in frogs and their unexpected diversity in the Atlantic forest of Brazil. BioScience 55(3):207-217.

HADDAD, C.F.B. \& SAZIMA, I. 1992. Anfíbios anuros da Serra do Japi. In História Natural da Serra do Japi: ecologia e preservação de uma área florestal no Sudeste do Brasil (L.P.C. Morellatto, org.). Editora da Unicamp/ FAPESP, Campinas, p.188-211.

HERO, J.-M. 1990. An illustrated key to tadpoles occurring in the Central Amazon forest, Manaus, Amazonas, Brazil. Amazoniana 11(2):201-262.

HEYER, W.R. 1985a. New species of frogs from Boracéia, São Paulo, Brazil. Proc. Biol. Soc. Wash. 98:657-671.

HEYER, W.R. 1985b. Taxonomic and natural history notes on frogs of the genus Centrolenella (Amphibia: Centrolenidae) from southeastern Brazil and adjacent Argentina. Pap. Avuls. Zool. 36(1):1-21.

HEYER, W.R., RAND, A.S., CRUZ, C.A.G. \& PEIXOTO, O.L. 1988 Decimations, extinctions, and colonizations of frog populations in southeast Brazil and their evolutionary implications. Biotropica 20:230-235.

HEYER, W.R., RAND, A.S., CRUZ, C.A.G., PEIXOTO, O.L. \& NELSON, C.E. 1990. Frogs of Boracéia. Arq. Zool. 31(4):231-410.

IUCN 2019. The IUCN Red List of Threatened Species. Version 2019-1. http:// www.iucnredlist.org. Downloaded on 02 April 2019.

IZECKSOHN, E. \& CARVALHO-E-SILVA, S.P. 2001. Anfíbios do município do Rio de Janeiro. Editora UFRJ. Rio de Janeiro.

KINDT, R. 2004. Biodiversity Analysis Functions for R (Biodiversity.R). ICRAF, Nairobi.
MARTINS, M. \& HADDAD, C.F.B. 1988. Vocalizations and reproductive behaviour in the Smith frog, Hyla faber Wied (Amphibia: Hylidae). Amphibia-Reptilia 9:49-60.

MORAES, R.A., SAWAYA, R.J. \& BARRELA, W. 2007. Composição e diversidade de anfíbios anuros em dois ambientes de Mata Atlântica no Parque Estadual Carlos Botelho, São Paulo, Sudeste do Brasil. Biota Neotropica. 7(2):27-36. https://doi.org/10.1590/S1676-06032007000200003 (last access on $08 / 10 / 2020$ ).

NARVAES, P., BERTOLUCI, J. \& RODRIGUES, M.T. 2009. Composição, uso de hábitat e estações reprodutivas das espécies de anuros da floresta de restinga da Estação Ecológica Juréia-Itatins, sudeste do Brasil. Biota Neotropica. 9(2):117-123. https://doi.org/10.1590/S1676-06032009000200011 (last access on $08 / 10 / 2020$ ).

OKSANEN, J., GUILLAUME BLANCHET, F., KINDT, R., LEGENDRE, P., MINCHIN, P.R., O'HARA, R.B., SIMPSON, G.L., SOLYMOS, P., STEVENS, M.H.H. \& WAGNER, H. 2012. Vegan: Community Ecology Package. R package version 2.0-3. http://CRAN.R-project.org/ package $=$ vegan (accessed on 28 July 2012).

PICKETT, S.T.A. \& WHITE, P.S. 1985.Patch dynamics: a synthesis. In: The Ecology of natural disturbance and patch dynamics. San Diego, Academic Press, p. 371-384.

POMBAL, J.P.JR. \& GORDO, M. 1991. Duas novas espécies de Hyla da floresta atlântica no estado de São Paul (Amphibia, Anura). Mem. Inst. Butantan 53:135-144.

R DEVELOPMENT CORE TEAM. 2012. R version 2.15.0: A language and environment for statistical computing. R Foundation for Statistical Computing, Vienna, Austria. http://www.R-project.org/ (accessed on 13 July 2012)

ROHLF, F.J. 2000. NTSYS-pc: numerical taxonomy and multivariate analysis system. Exeter Software, Setauket, NY.

ROSSA-FERES, D.C., SAWAYA, R.J., FAIVOVICH, J., GIOVANELLI, J.G.R., BRASILEIRO, C.A., SCHIESARI, L., ALEXANDRINO, J. E \& HADDAD, C.F.B. 2011. Anfíbios do Estado de São Paulo, Brasil: Conhecimento Atual e Perspectivas. Biota Neotropica. 11(1a):47-66. https:// doi.org/10.1590/S1676-06032011000500004 (last access on 08/10/2020).

RUDOLF, V.H.W. \& RÖDEL, M.O. 2005. Oviposition site selection in a complex and variable environment: the role of habitat quality and conspecific cues. Oecologia 142: 316-325.

SANTOS, A.J. 2003. Estimativas de riqueza em espécies. In Métodos de estudos em biologia da conservação e manejo da vida silvestre (L. Cullen Jr., R. Pudran \& C.Valladares-Pádua, eds.). Editora da UFPR, Curitiba, p. 19-41.

SETZER, J. 1946. Contribuição para o estudo do clima do Estado de São Paulo. São Paulo: Escolas Profissionais Salesianas.

SILVA, R.A., MARTINS, I.A. \& ROSSA-FERES, D.C. 2011. Environmental heterogeneity: Anuran diversity in homogeneous environments. Zoologia 28(5):610-618.

SNEATH, P.H.A. \& SOKAL, R.R. 1973. Numerical Taxonomy. Freeman. San Francisco.

TOCHER, M.D., GASCON, C. \& MEYER, J. 2001.Community composition and breeding sucesso f Amazonian frogs in contínuos forest and matrix habita aquatic sites. In: Lessons from Amazonia: the ecology and conservation of a fragments forest.(R.O. Bierregard, C. Gascon, T. E. Lovejoy \& R. C. Mesquita, eds.). Yale University Press, New Haven \& London. p.235-247.

TREVINE, V., FORLANI, M.C., HADDAD, C.F.B. \& ZAHER, H. 2014. Herpetofauna of Paranapiacaba: expanding our knowledge on a historical region in the Atlantic forest of southeastern Brazil. Zoologia 31(2):126-146.

UNDERWOOD, A.J., CHAPMAN, M.G. \& CONNELL, S.D. 2000. Observations in ecology: you can't make progress on processes without understanding the patterns. J. Exp. Mar. Biol. Ecol. 250:97-115.

VANCINE, M.H., K.S., DUARTE, K.S., SOUZA, Y.S., GIOVANELLI, J.G.R., MARTINS-SOBRINHO, P.M., LÓPEZ, A., BOVO, R.P., MAFFEI, F., LION, M.B., RIBEIRO-JÚNIOR, J.W., BRASSALOTI, R., COSTA, sEPP.C.O.R., SAWAKUCHI, H.O., FORTI, L.R., CACCIALI, P., BERTOLUCI, SEP.]., HADDAD, C.F.B. \& RIBEIRO, M.C. 2018. ATLANTIC AMPHIBIANS: a data set of amphibian communities from the Atlantic Forests of South America. Ecology 99:1692. 
VASCONCELOS, T.S. \& ROSSA-FERES, D.C. 2008. Habitat heterogeneity and use of physical and acoustic space in anuran communities in southeastern Brazil. Phyllomedusa 7(2):125-140.

VASCONCELOS, T.S., SANTOS, T.G., ROSSA-FERES, D.C. \& HADDAD, C.F.B. 2009. Influence of the environmental heterogeneity of breeding ponds on anuran assemblages from southeastern Brazil. Can. J. Zool. 87:699-707.

VAZ-FERREIRA, R. \& GERHAU, A. 1975. Comportamiento epimelético de la rana común Leptodactylus ocellatus (L.) (Amphibia, Leptodactylidae) I. Atención de la cría y actividades alimentarias y agresivas relacionadas. Physis 34(88):1-14.

VELOSO, H.P., RANGEL-FILHO, A.L. \& LIMA, J.C.A. 1991. Classificação da vegetação brasileira adaptada a um sistema universal. Rio de Janeiro (Brasil): IBGE.

VERDADE, V.K., RODRIGUES, M.T. \& PAVAN, D. 2009. Anfíbios anuros da região da Estação Biológica do Alto da Serra de Paranapiacaba. In Patrimônio da Reserva Biológica do Alto da Serra de Paranapiacaba. A antiga Estação Biológica do Alto da Serra (M.I.M.S. Lopes, M. Kirizawa \& M.M.R.F. Melo, orgs.). Secretaria do Meio Ambiente do Estado de São Paulo, São Paulo. p.579-604.

VERDADE, V.K., CARNAVAL, A.C., RODRIGUES, M.T., SCHIESARI, L., PAVAN, D. \& BERTOLUCI, J. 2011. Decline of Amphibians in Brazil. In: Harold Heatwole; John W. Wilkinson (orgs.). Status of Decline of Amphibians: Western Hemisphere. Part 2: Uruguay, Brazil, Ecuador and Colombia. Series Amphibian Biology. Chipping Norton, NSW: Surrey Beatty \& Sons, v. 9, p. 85-127.
VERDADE, V.K, VALDUJO, P.H., CARNAVAL, A.C., SCHIESARI, L., TOLEDO, L.F., MOTT, T., ANDRADE, G.V., ETEROVICK, P.C., MENIN, M., PIMENTA, B.V.S., NOGUEIRA, C., LISBOA, C.S., DE PAULA, C.D. \& SILVANO, D.L. 2012. A leap further: the Brazilian Amphibian Conservation Action Plan. Alytes 29(1-4):8-43.

VILELA, V.M.F.N., BRASSALOTI, R.A. \& BERTOLUCI, J. 2011. Anurofauna da floresta de restinga do Parque Estadual da Ilha do Cardoso, Sudeste do Brasil: composição de espécies e uso de sítios reprodutivos. Biota Neotropica. 11(1):83-93. http://dx.doi.org/10.1590/S1676-06032011000100008 (last access on $08 / 10 / 2020$ ).

WELLS, K.D. 2007. The Ecology and Behavior of Amphibians. Chicago (Illinois): University of Chicago Press.

WEYGOLDT, P. 1989. Changes in the composition of mountain stream frog communities in the Atlantic mountains of Brazil: Frogs as indicators of environmental deteriorations? Stud. Neotrop. Fauna Environ. 243:249-255.

WOEHL, G. \& WOEHL, E.N. 2000. Pererecas protetoras da mata atlântica sob ameaça. Ciência Hoje 28(164):72-74.

Received: 20/07/2020

Revised: 05/11/2020

Accepted: 09/11/2020

Published online: 13/01/2021| 